\title{
CORRECTION
}

\section{Correction to: Hum Gene Ther 2016;27(1):19-31}

IN THE JANUARY 2016 ISSUE of Human Gene Therapy (vol. 27, no. 1, pp. 19-31), the article "Therapeutic rAAVrh10 Mediated SOD1 Silencing in Adult SOD1 ${ }^{\mathrm{G} 93 \mathrm{~A}}$ Mice and Nonhuman Primates," by Dr. Florie Borel et al., has listed the name of one of the coauthors incorrectly.

"Gabriela C. Toro Cabreja" should have been listed as "Gabriela T. Cabrera."

The online version of the article has been corrected to reflect this change.

The authors wish to apologize for the error. 